\title{
Koulutus on enemmän miesten kuin naisten menestystekijä
}

\author{
Päivi Naumanen
}

\author{
Koulutus on menestystekijä - etenkin miehille. Mutta \\ menestys ei ole kiinni ainoastaan koulutuksesta tai \\ sukupuolesta, vaan se on sidoksissa moniin muihinkin \\ sosiaalisiin ominaisuuksiin. Kun työllisyystilanne heikke- \\ nee ja koulutettua työvoimaa on runsaasti tarjolla, mui- \\ den tekijöiden kuin koulutuksen merkitys yleensä kasvaa.
}

$\mathrm{K}$ un aloin 90-luvun loppupuolella tehdä tutkimustani "Koulutuksella kilpailukykyä Koulutuksen yhteys miesten ja naisten työllisyyteen ja työn sisältöön", sukupuolten tasa-arvo tuntui hieman epämuodikkaalta aiheelta, ehkä vanhentuneeltakin.

Tuntemukseeni vaikutti todennäköisesti ajankohdalle ominainen poliittinen ja kulttuurinen ilmapiiri sekä lisäksi se, että yhteiskuntatieteellisessä tutkimuksessa oli jo jonkin aikaa keskitytty analysoimaan merkityksiä ja identiteettejä. Suuren laman jälkimainingeissa suomalainen yhteiskuntapoliittinen ilmasto oli vielä sakeana markkinaliberalistista puhetta. Ajan hengen mukaan ajatus kuului: jokainen yksilö luo menestyksensä itse niin markkinatoimijana kuin oman elämänsä mestarinakin. Tasa-arvokeskustelulle ei näyttänyt löytyvän sijaa tehokkuutta ja kilpailua korostavassa diskurssissa.

Toisaalta on todettava se, että suomalaiseen kulttuuriin on perinteisestikin kuulunut voimakas yksilön korostus. Olemme ensisijaisesti ihmisiä, emme miehiä ja naisia. Jokainen meistä on yhtä lailla yksilö, joka käyttää omia kykyjään ja mahdollisuuksiaan omaksi parhaakseen.

$\mathrm{K}$ ansalaisille tasa-arvo on toki edelleen tärkeä avoite. Viimeisimmän tasa-arvobarometrin mukaan niin suomalaisten naisten kuin miestenkin enemmistö on sitä mieltä, että yhteis- kunnan pitäisi olla tasa-arvoisempi eri sukupuolille. Sekä miehet että naiset pitävät molempien sukupuolten osallistumista politiikkaan tarpeellisena, jotta asiantuntemus olisi monipuolista. Naisten työssäkäyntiä pidetään selviönä perhetilanteeseen katsomatta, ja molempien sukupuolten mielestä miesten tulisi nykyistä enemmän ottaa vastuuta lastenkasvatuksesta ja muusta perheen huoltamisesta.

Eriarvoisuuden havaitseminen riippuu sukupuolesta. Viisi naista kuudesta ja kaksi miestä kolmesta pitää miesten asemaa yhteiskunnassa parempana kuin naisten. Työelämässä toimivista naisista joka toinen kokee haittaa omasta sukupuolestaan. Haitta näkyy useimmiten pienempänä palkkana, vähäisenä ammattitaidon arvostuksena ja takkuisempana etenemisenä uralla. Joka kolmas tyttö tai nainen on sitä mieltä, että poikien ja miesten maailma ylikorostuu koulujen oppisisällöissä.

Kun naisten ongelmat liittyvät miehiä heikompiin työmarkkinamahdollisuuksiin, työn arvostukseen ja palkkaukseen, miesten ongelmat liittyvät enemmän arkielämän ja oman elämän hallintaan.

Cukupuolta koskevassa yhteiskuntatutkimukses Sa tasa-arvon merkityssisältö on muuttunut kolmen tai neljän viime vuosikymmenen aikana. Alun perin lähtökohtana oli tukea naisia saa- 
vuttamaan miesten kanssa yhtäläinen asema. Miesten asemaa pidettiin mittana ja tavoitteena, johon naisten tuli pyrkiä. Sittemmin on haluttu korostaa naisten työn ja elämänalueiden erityisyyttä. Pyrkimyksenä on ollut, että naisten saavutukset ja suoritukset - naisten työnjaolliset alueet, tiedot ja taidot - saavat tunnustusta ja arvostusta - ilman, että niitä pakonomaisesti vertaillaan miesten saavutuksiin ja suorituksiin.

Nykyisemmin sukupuolta koskevassa akateemisessa tutkimuksessa ei ole keskeistä sen selvittäminen, minkälaisissa asemissa ja tilanteissa miehet ja naiset elävät; minkälaisia töitä he tekevät tai minkälaista palkkaa he ansaitsevat. Tärkeämpänä pidetään sen tutkimista, minkälaisia merkityksiä miehet ja naiset itse antavat toiminnoilleen, töilleen ja ansioilleen. Rakenteellisesta vertailusta ja erityisyyden etsimisestä on siirrytty tutkimaan sitä, millä tavoin sukupuolta esitetään ja miten sukupuolen mukaisia jakoja tuotetaan erilaisissa paikoissa, erilaisina aikoina ja erilaisissa puheissa.

Kuten tutkimukseni toinen esitarkastaja, dosentti Anna-Maija Lehto, on todennut, on yhä vaikeampaa nähdä selkeää yhteyttä sukupuolta koskevan tutkimuksen ja tasa-arvopoliittisten tavoitteiden välillä. Tällaisen yhteyden etsiminen olisi kuitenkin tärkeää.

Nykyisin tasa-arvolla tarkoitetaan miesten ja naisten yhtäläisiä tai samanarvoisia mahdollisuuksia pyrkiä niihin tavoitteisiin tai päämääriin, joita he itse pitävät tärkeinä ja arvostavat.

$\mathrm{M}$ ääritelmän mukaan hyväksymme erilaisuu den tasa-arvon lähtökohtana. Käytännössä on kuitenkin mahdotonta ohittaa kysymystä erilaisuuden ja eriarvon välisestä yhteydestä. Väitöstutkimukseni äärellä olen monta kertaa joutunut miettimään sitä, seuraako erilaisuudesta vääjäämättä erilaista arvoa ja arvostusta työmarkkinoilla. Ymmärrykseni mukaan erilaisuus ei sinällään tuota eriarvoa, mutta kun erilaisuuteen liittyy yhteiskunnallisissa käytännöissä valtaa ja epäsymmetristä vaihtoa, syntyy eriarvoisuutta. Onkin vaikeampaa löytää konkreettisia esimerkkejä erilaisten samanarvoisuudesta kuin erilaisten eriarvoisuudesta. Menestys ei kerta kaikkiaan jakaudu satunnaisesti erilaisten ihmisten kesken, vaan on sitkeästi sidoksissa juuri erilaisuuteen. Käy-

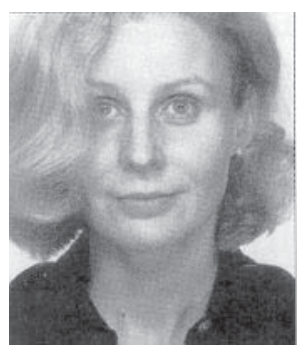

Päivi Naumanen

tännössä erilaisuus eriarvoistaa, vaikka näin ei monen mielestä tarvitsisi eikä pitäisi olla. Erilaisuutta käytetään myös legitimoimaan eriarvoisuutta.

Jos lähdemmekin siitä, että tasa-arvon toteutumisen mittapuuksi otetaan yksilöiden omat tavoitteet ja toiveet, emme silti voi jättää huomiotta ja tutkimatta erilaisuudesta juontuvaa eriarvoa. Yksilöiden menestykselle antamat merkitykset sekä menestyksen toiveet ja tavoitteet vaihtelevat ja voivat olla hyvinkin erilaisia. Kuitenkin menestyminen, kuten vaikkapa työn saanti, on monien toiveiden ja tavoitteiden toteutumisen edellytys. Tässä katsannossa erilainen pärjääminen eriarvoistaa riippumatta siitä, onko tämä pärjääminen yksilön tavoitteena vai ei. Tämän takia on mielestäni ensiarvoisen tärkeää tutkia sitä, miten miehet ja naiset pärjäävät.

$\mathrm{K}$ oulutusta on pidetty tärkeänä keinona vä entää erilaisuudesta juontuvaa eriarvoisuutta. Yhtäläisen koulutuksen voi nähdä osaltaan tasoittaneen yksilöiden erilaisia lähtökohtia ja mahdollisuuksia. Mutta yhtäläinenkään koulutus ei ole kyennyt tasaamaan eri sukupuolten mahdollisuuksia siinä määrin, että eriarvo olisi hävinnyt tai ratkaisevasti vähentynyt. Koulutus sosiaalisena instituutiona onkin yhteiskunnan sisällä, osa muuta yhteiskuntaa. Siten koulutuksessa pätevät paljolti samat lainalaisuudet kuin muualla yhteiskunnassa. Pelkästään koulutuksen keinoin ei voida poistaa eriarvoa, joka vallitsee ympäröivässä yhteiskunnassa, ja jonka koulutuksen hankkineet - sen pituudesta tai laadusta riippumatta - joutuvat joka tapauksessa kohtamaan siirtyessään koulusta muuhun yhteiskuntaan.

Tutkimukseni lähtökohtana ovat olleet ha- 
vainnot siitä, että suomalaiset naiset kouluttautuvat ahkerasti, ja ovat nykyisin koulutetumpia kuin miehet. Toisaalta monien tutkimustulosten mukaan naiset menestyvät työmarkkinoilla miehiä huonommin. Mikä on siis koulutuksen ja menestyksen suhde? Onko se erilainen eri sukupuolilla? Toimiiko koulutus yksien kohdalla paremmin kuin toisten, vieläpä systemaattisesti? Tutkimukseni mukaan näin on. Mutta menestys ei ole kiinni ainoastaan koulutuksesta tai sukupuolesta, vaan menestys on sidoksissa moniin muihinkin sosiaalisiin ominaisuuksiin. Kun työllisyystilanne heikkenee ja koulutettua työvoimaa on runsaasti tarjolla, muiden tekijöiden kuin koulutuksen merkitys yleensä kasvaa. Vuosituhannen vaihteen työmarkkinoilla naissukupuoli yhdistettynä nuoreen ikään ja korkeaan koulutukseen näyttäisi olevan työllisyyden vakauden ja työn sisällön laadun kannalta melko kehno kilpailuvaltti.

Tutkimuksessani olen kuvannut poikkileikkausaineistojen tarjoamien mahdollisuuksien varassa sitä, missä määrin miesten ja naisten koulutustaso - koulutuksen määrä tai pituus - ja toisaalta lisäkoulutushalukkuus ovat yhteydessä työkansalaisen pärjäämisen kannalta tärkeisiin työllisyyden ja työn sisällön ulottuvuuksiin. Tämän pohjalta olen yrittänyt tehdä päätelmiä siitä, minkälainen työmarkkinaresurssi koulutus on suomalaisille miehille ja naisille. Mutta mikä on analyysin pätevyysalue?

$\mathrm{L}$ ectioni lopuksi arvioin lyhyesti tutkimuksen rajoituksia; mitä tässä jäi selvittämättä, mitkä ovat analyysin puutteet ja mitä jatkossa kannattaisi tutkia. Ensinnäkin tutkimuksessa jäi selvittämättä se tärkeä kysymys, miten koulutuksen laatu on yhteydessä miesten ja naisten työllisyyteen ja työn sisältöön. Tutkimuksessani tarkastelun keskiössä on koulutustaso, koska se kuvaa koulutusalaa selkeämmin kouluttautumista investointina; missä määrin koulutukseen käytetään aikaa, rahaa ja vaivaa. Koulutusalan merkitys miesten ja naisten työmarkkinoilla pärjäämisen kannalta on mielestäni kuitenkin sen verran tärkeä kysymys, että se vaatisi kokonaan oman tutkimuksensa.

Toiseksi tutkimuksen päätelmät koulutuksen "vaikutuksista" perustuvat siihen, että muuttu- jien välillä havaitaan ja lasketaan tilastollisia yhteyksiä ja todennäköisyyksiä - arvioita jonkun ilmiön esiintymisen todennäköisyydestä, kun otetaan huomioon eräiden muiden ilmiöiden yht'aikainen esiintyminen tai niiden esiintymisen todennäköisyys. Oikeaoppinen kausaalisuhteiden selvittäminen edellyttäisi pitkittäis- tai paneelitutkimusta, jonka avulla voitaisiin seurata ja vertailla tutkintoja hankkineiden ja tutkinnottomien miesten ja naisten markkina- ja työtilanteiden muotoutumista tietyllä aikavälillä. Vasta tällä tavoin saataisiin vastaus kysymykseen, miten koulutus vaikuttaa miesten ja naisten menestymiseen. Käytännössä tällaisia aineistoja on kuitenkin harvemmin tarjolla tutkijoille.

Kolmanneksi tämän tutkimuksen analyysit ja päätelmät koulutuksesta miesten ja naisten menestymisen resurssina pätevät vain ja ainoastaan siinä laajuudessa kuin me uskomme, että tutkimuksessa käytettävät mittarit eli haastattelukysymykset todella tavoittavat miesten ja naisten pärjäämisen työmarkkinoilla ja työssä. Mielestäni tutkimuksen kysymykset mittaavat hyvin miesten ja naisten pärjäämistä sukupuolineutraalin palkkatyökansalaisen ideaa vasten. Ne eivät välttämättä mittaa sellaista menestymistä, mitä miehet ja naiset markkinoilla ja työssä tavoittelevat tai itse pitävät tärkeinä. Lisäksi ne todennäköisesti mittaavat puutteellisemmin naistyökansalaisen ja palkkatyövanhemman pärjäämistä kuin miestyökansalaisen ja "elättäjän" pärjäämistä. Naisten työn laatu ja naisten työn vaativuus eivät kovin hyvin välity tämän tutkimuksen empiirisillä kysymyksillä, koska ne ovat rakennettuja pääosin miestyökansalaisen idean ja sen käsitteen varassa kerätyn empiirisen tutkimustiedon perustalle. Naisten työn laadun ja erityisyyden tavoittaminen edellyttäisi myös sellaisia tutkimuskysymyksiä, jotka perustuvat naistyökansalaisen ja palkkatyövanhemman ideaan.

PäiviNaumanen (2002). Koulutuksellakilpailukykyä-Koulutuksenyhteys miesten ja naisten työllisyyteen jatyön sisältöön. Turunyliopisto.

Yliassistentti Päivi Naumanenväitteli Turunyliopistossa 17.5.2002 vastaväittäjänä dosentti Jouko Nätti Jyväskylän yliopistosta. Edelläoleva tekstion lectio praecursario. 